\title{
POVERTY ELEVATION AMIDST POVERTY ALLEVIATION PROGRAMMES IN NIGERIA
}

\author{
Obiwuru Chidera Rex ${ }^{1}$ \\ ${ }_{1}$ Department of Politics and International Relations Esep Le Berger Univeristy, Benin Republic
}

\begin{abstract}
Purpose of the study: Nigerian government has pursued myriads of poverty alleviation programmes for the ultimate purpose of mitigating poverty in the country. However, amidst the programmes, poverty still rabidly refused to get mitigated. Thus, the objectives of this study would be (a) to pinpoint some capital reasons for the persistence of extreme poverty in the country; and (b) to provide some panaceas to the issue. However, before this, the study would look at some poverty alleviation programmes in Nigeria.
\end{abstract}

Methodology: This is exploratory research that is based on secondary research method. Data used were generated from textbooks, online newspapers, journal articles, organizational reports, etc.

Findings: Findings of this study demonstrate that erraticness of programmes/policies, corruption and mismanagement, hypocrisy on the part of World Bank and IMF, imitation of other countries' policies without proper consideration of the peculiarities of the Nigerian society/system, political deception and interference, etc. are responsible for the mushrooming of poverty in Nigeria even in the midst of poverty alleviation programmes.

Application: This study will be of great help to Nigerian potentates/leaders and organizations who sincerely want to tackle the issue of poverty in the country. It will enable them to see the reasons for the unsuccessfulness of past and present poverty alleviation programmes in the country and the way out.

Novelty/Originality: The study will be highly useful to students, lecturers and future researchers in the field of political science, mainly in Nigeria. For future researchers, particularly, the study will serve as a springboard for further research on the hindrances to the success of poverty alleviation programmes in the country.

Keywords: Alleviation Programs, Poverty, Persistence, Nigeria.

\section{INTRODUCTION}

Poverty is not nonexistent in any country in the world. In other words, it is present in all countries of the world, whether developed or underdeveloped. However, the magnitude of poverty in Africa in general and Nigeria, in particular, is oppressive and shocking. One threat that poverty possesses in any place where its rate is quite high is crime augmentation. Poverty frustrates. It can propel a man into doing what is morally, ethically and socially wrong. This is no lie because poverty is one of the cardinal mothers of crime in different human societies.

It is based on the above that the Nigerian government, together with non-governmental organizations went in search of and came up with different policies and programmes at different times aimed at "banishing" the crime-augmenting agent - poverty from the country. This is evident in the policies almost every regime had pursued in Nigeria many decades and years ago (and even presently). Some of the policies/programmes include Operation Feed the Nation (OFN) under General Olusegun Obasanjo, Green Revolution under Shehu Shagari, Structural Adjustment Programme under General Ibrahim Babangida and so forth. Nevertheless, regardless of this, multitudinous Nigerians still lived (and live) below poverty line, which is present at $\$ 1.90$ per day. For this reason, Aiyedogbon and Ohwofasa (2012) and Taiwo and Agwu (2016) note that "in spite the vast resources committed to poverty alleviation by every successive administration, no obvious achievement has been accomplished in this direction."

However, the "unsuccessfulness" of the programmes or the acceleration of poverty in the country is not because Nigeria is (or was) without enough human and capital resources to alleviate it, for Nigeria has all it takes to save its

Corresponding Author: ${ }^{1}$ Kapitoo1000@gmail.com 
people from scourging poverty. Nevertheless, there are several factors constituting an obstacle to the success of the programmes, and these we would be looking at in the later part of this study after we must have done justice to the concepts of poverty and poverty alleviation, and examine various programmes aimed at poverty reduction in the country.

\title{
2. LITERATURE REVIEW
}

\subsection{Concept of Poverty}

For any individual to stand and say that poverty has a frictionless or a universally sole definition, the person must be committing a blunder or is an ignoramus. This is because there is no sole or all-inclusive definition of poverty.

However, poverty can be viewed as a condition of financial incapacitation which prevents one from providing for one's own essential needs such as food, clean water, cloth, shelter, education and healthcare. A clear example of poverty can be seen in one poor man's statement in 1997. The poor man who was from Kenya said:

\author{
Do not ask me what poverty is because you have met it outside my \\ house. Look at the house and count the number of holes. Look at my \\ utensils and the clothes that I am wearing. Look at everything and \\ write what you see. What you see is poverty. \\ In Vietnam in 1999, another poor man made a statement that depicts \\ poverty. He said: \\ In the evenings, eat sweet potatoes, sleep \\ In the mornings, eat potatoes, work \\ At lunch, go without (see siteresources.worldbark.org, 2019).
}

The United Nations, in its 2004 publication titled "Human Rights and Poverty Reduction: A Conceptual Framework," defined poverty, with respect to human rights, as "a denial or non-fulfillment of human rights." The rights, according to the organization, include fundamental freedoms like "freedoms from hunger, disease and illiteracy." It also looked at poverty as "low levels of capability (i.e. a person's freedom or opportunities to achieve well-being)" and "the failure of basic capabilities, as Sen puts it, to reach certain minimally acceptable levels" (pp. 5-6).

United Nations Educational, Scientific and Cultural Organization (UNESCO), on the other hand, noted that poverty could be defined in either relative or absolute terms. Absolute poverty, it notes, "measures poverty in relation to the amount of money necessary to meet basic needs such as food, clothing, and shelter" while relative poverty has to do with "the economic status" of individuals. In relative terms, "people are poor if they fall below prevailing standards of living in a given societal context" (Mohammed, 2018).

According to World Bank (1999) poverty refers to "shortage of food, lack of shelter, being ill, and not being able to go to school, not being able to read, fear for the future, not having a job, not being able to speak correctly, losing a child due to illness brought about by dirty water, lack of representation, powerlessness, not being able to speak correctly and inadequate freedom". In 2011, World Bank also defined poverty as "distinct deprivation in the living condition which comprises multiple dimensions; these include inability to have access to basic needs..." (Musa et al., 2016). To same financial institution again, poverty means living on less than $\$ 1.90$ a day (Vyas \& Bhargava, 1995).

Be that as it may, the condition of being poor in the Nigerian context has to do with the following:

i. Households or individuals below the poverty line and whose incomes are insufficient to provide for their basic needs.

ii. Households or individuals lack access to basic services, political contracts and other forms of support.

iii. People who are in isolated rural areas lack essential infrastructures.

iv. $\quad$ Female-headed households whose nutritional needs are not being met adequately.

v. Persons who have lost their jobs and are unable to find employment as a result of economic reforms.

vi. Ethnic minorities are marginalized, deprived and persecuted economically, socially, culturally and politically (Taiwo and Agwu, 2016). 


\subsection{Poverty Alleviation}

Poverty alleviation, also known as poverty reduction, is geared generally towards saving humanity from reproachful poverty mainly through empowerment and education, thereby enabling people to cater to their own personal and family basic needs.

It aims at "promoting economic growth that will permanently lift as many people as possible over a poverty line" (Barder, 2009). It concerns itself with the technical lifting of "people out of poverty." However, it has "no role in regard to voluntary poverty," which arises from people's religious and philosophical beliefs (Vyas \& Bhargava, 1995).

It can be achieved globally and locally by/through individuals', organizations' and government's sincere efforts to end poverty.

\section{A CONSIDERATION OF POVERTY ALLEVIATION PROGRAMMES IN NIGERIA}

Different financial institutions, non-governmental organizations and the Nigerian government in particular have embarked on series of poverty alleviation programmes that would see Nigerians being emancipated from the bondage of poverty through, to borrow the words of Musa et al. (2016), "capacity building", "employment generation to the less privileges and tertiary institution graduates", "skills acquisition", "generation of income to boost agricultural output" among others. It should be noted that the desire to mitigate poverty in the country is not of recent development. Evidence of this can be seen in the 1960s poverty alleviation programme called Farm Settlement Option, which was aimed at agricultural improvement for exportation of cash crops.

In 1972 and 1973, after the collapse of the programme, the government again cane up with National Accelerated Food Production Project (NAFPP) and Agricultural Development Project (ADJ), respectively. The reasons behind the development of these programmes were these: "to create an avenue for testing and adapting agricultural findings and making such available to farmers" all over the country, and "to provide credit facilities for the development of agricultural projects in order to promote integrated rural developments." To ensure the success of the programmes (ADJ in particular), the World Bank had to partly finance and see to their execution (Taiwo and Agwu, 2016).

On May 20, 1976, General Olusegun Obasanjo, about three months after he took overpower from the deceased General Muritala Mohammed, launched Operation Feed the Nation (OFN). The goals of OFN were: "to drastically boost local food production (which would reduce imports)," "to diminish rural-urban migration due to the abandonment of agriculture," and to increase employment for the youths through "return to farm" agenda (Mohammed, 2018). In 1977 and 1978, during the same Obasanjo's regime, Rural Banking Scheme, aimed at bringing banking nearer to the rural dwellers through provision of credit facilities, and Austerity Measures which was all about the prohibition of importation of certain commodities were respectively adopted (Taiwo and Agwu, 2016).

In April 1980, Alhaji Shehu Shagari, after he had emerged the President of Nigeria in 1979, launched yet another poverty alleviation programme called Green Revolution. The objective of the programme, among others was to drive the country into "the realm of self-sufficiency in farm produce and food surplusage," thereby ejecting Nigerians from hunger and lack. In the same vein, Shagari's government introduced Federal Housing Scheme in which a total of N2.6 billion was earmarked for the implementation of the programme which would see to the provision of affordable houses for low-income earners whose annual income did not exceed five thousand nairas (N5000.00) and medium-income group with annual income not exceeding eight thousand nairas (N8000.00). The government embarked on erecting 40,000 units every year with 2000 per state and the FCT (Irouke et al., 2017). Through this, shelter purpose of poor Nigerians was to be met.

Later on, the Structural Adjustment Programme (SAP) was adopted in 1986 under the regime of General Ibrahim Babangida. The programme was targeted at the country's economic growth free of inflation. In 1987, we had the Better Life Programme (BLP), which was primarily focused on skill acquisition, health care and rural development. Nevertheless, before this, we had the National Directorate of Employment (NDE), which tried to employ Nigerian youths, and the Directorate for Foods, Roads and Rural Infrastructures (DFRRI), which was also geared towards rural development. In 1994 and 1997, the Family Support Programme 
(FSP) Furthermore, the Family Economic Advancement Programme (FEAP) were launched respectively for the ultimate purposes of betterment of the lives of Nigerians, through support for child welfare, youth development, and provision of credit facilities to aid the establishment of cottage industries (Taiwo and Agwu, 2016).

On return to democratic rule in 1999, the government, particularly, upon realizing that about $70 \%$ of Nigerians were completely wallowing in destitution, launched the Poverty Alleviation Programme (PAP), which provided 200,000 jobs for the unemployed Nigerians. However, even with this, poverty never reduced as expected, and thus the government came up with the National Poverty Eradication Programme (NAPEP) in 2001. The government also provided the sum of six billion nairas for the eradication of poverty in the country. However, before the full commencement of its sacrosanct assignment, NAPEP was structured into four schemes which were: i. Youth Empowerment Scheme (YES); ii. Rural Infrastructure Development Scheme (RIDS); iii. Social Welfare Service Scheme (SOWEESS); iv. Natural Resources Development and Conservation Scheme (NRDCS) (Hussaini, 2014).

In 2004 came the launching of the National Economic Empowerment and Development Strategy (NEEDS). At the state level, NEEDS was called the State Economic Empowerment and Development Strategy (SEEDS), while at the local level it was called the Local Economic Empowerment and Development Strategy (LEEDS). It tried, with the help of different NGOs, ministries and parastatals, to fight corruption; ensure transparency; promote a sane society governed by the rule of law; ensure job or employment creation; promote education, people's health and security, among others. Later in 2007 after the emergence of Musa Yar' Adua as the Nigerian president, he came up with his Seven-Point Agenda, which tried to deal with the issue of erratic power/electricity, ensure food security and human capital development, and so forth. In 2016 after President Muhammadu Buhari came to the helm of Nigeria through the 2015 General elections, he set aside the sum of 500 billion nairas for poverty eradication in the country. He later launched the N-Power, which aims at "empowering Nigerian youths for prosperity" by "providing a structure for large scale and relevant work skills acquisition and development." This is supposed to see to the emergence of "software developers, hardware service professionals, animators, graphic artists, building services professionals, artisans and others," thereby lambasting and igniting poverty and unemployment among the youths (Mohammed, 2018).

\section{POVERTY ELEVATION IN NIGERIA}

Despite the myriads of poverty alleviation programmes we have seen above; poverty has never stopped soaring in Nigeria. According to Okunmadewa et al. (2005) and Olotu, Salami, and Akeremale (2015), the poverty situation in Nigeria is quite disturbing; both the quantitative and qualitative measurements attest to the accelerating incidence and depth of poverty in the country. National Bureau of Statistics also stated that since independence, there had been deterioration of the quality of life of Nigerians, which has resulted in steady increase in the number of Nigerians caught below the poverty line (Olotu et al., 2015).

Amidst poverty alleviation programmes we had between 1980 and 1996, poverty kept on accelerating in the country. An example of this can be seen in the tables below.

Table 1:

Poverty Head Count by Year

\begin{tabular}{lllc}
\hline Year & $\begin{array}{l}\text { Poverty } \\
\text { Incidence (\%) }\end{array}$ & $\begin{array}{c}\text { Est. Pop. } \\
\text { (million) }\end{array}$ & $\begin{array}{c}\text { Pop. in poverty } \\
\text { (million) }\end{array}$ \\
\hline 1980 & 28.1 & 65 & 17.7 \\
1985 & 46.3 & 75 & 34.7 \\
1992 & 42.7 & 91.5 & 39.2 \\
1996 & 65.6 & 102.3 & 67.1 \\
\hline
\end{tabular}

Source: National Bureau of Statistics (NBS), 2005

From the above, it could be seen that there was an acceleration of poverty incidence in the country all from 1980 to 1996 except in 1992 that it reduced by 3.6\%. Meanwhile Nigeria's population in poverty never reduced all through the same period; rather it increased four-fold.

Table 2: 
The Poor and the Core Poor by Year

\begin{tabular}{rccc}
\hline Year & None Poor (\%) & Mod. Poor (\%) & Core Poor (\%) \\
\hline 1980 & 72.8 & 21.0 & 6.2 \\
1985 & $53 . .7$ & 34.2 & 12.1 \\
1992 & 57.3 & 28.9 & 13.9 \\
1996 & 34.4 & 36.3 & 29.3
\end{tabular}

Source: National Bureau of Statistics (NBS), 2005

In Table 2, we could see how the percentage of non-poor Nigerians was decreasing except in 1992; the percentage of moderate poor accelerated all through also except in 1992, while the percentage of the core poor increased from $6.2 \%$ in 1980 to $29.3 \%$ in 1996 .

Table 3:

Poverty Trends by Sector

\begin{tabular}{ccc}
\hline Year & $\begin{array}{c}\text { Urban } \\
(\mathbf{\%})\end{array}$ & Rural \\
\hline 1980 & 17.2 & 28.3 \\
1985 & 37.8 & 51.4 \\
1992 & 37.5 & 46.0 \\
1996 & 58.2 & 69.8 \\
\hline
\end{tabular}

Source: National Bureau of Statistics (NBS), 2005

Between 1980 and 1996, the percentage of poverty by sector in both urban and rural areas, according to what we have in Table 3 above, augmented all through except in 1992.

Lastly, and heartbreakingly, Nigeria, even with all its poverty reduction programmes, scored 0.391 in Human Development Index (HDI) in 1998, ranking as 142 out of the 174 countries which were surveyed. In 2000, the HDI score for same Nigeria was 0.439 , with the rank 151 out of 174 countries. In 2002, its HDI score was 0.466 , with its position as 151 out of the surveyed 177 countries (Olotu et al., 2015). In terms of living standards, Nigeria ranked 152 out of 188 countries considered in 2016 (UN report). The unemployment rate, according to the same report, reached $42 \%$, with 80 million Nigerians living for $\$ 1.25$ a day; meaning, they live below poverty line (Olotu et al., 2015).

\section{REASONS FOR THE ACCELERATION OF POVERTY IN NIGERIA despite THE POVERTY ALLEVIATION PROGRAMMES}

History is there to prove that it had (and has) been the desire of every government in Nigeria to end poverty among Nigerians and in Nigeria, as we have above. Nevertheless, as UN reported, 80 million Nigerians, roughly half of Nigeria's population, still live in extreme poverty. Be that as it may, the following are some of the pivotal reasons why poverty has persisted in Nigeria despite the frequent launching of poverty alleviation programs in the country:

- Erraticness of programmes: Launching poverty alleviation programmes is vividly a ritual for Nigerian government. As soon as a government goes and a new one comes, the programmes and policies of the old regime are immediately jettisoned whether or not the policies and programmes are on the verge of success. Hence, we have in Nigeria, new government new programmes/policies. Considering this, therefore, it becomes difficult to alleviate poverty in the country.

- Corruption and Mismanagement: Corruption generally is a reproach. In Nigeria, corruption is, no doubt, at its peak. The Petroleum Trust Fund (PTF) created under Abacha's regime and headed by General Oral Buhari as its Chief Executive, for example, witnessed hyper misappropriation Reno (1999) note:

"At the end of the PTF experiment, Nigeria's poverty and underdevelopment level remained the same, if not worse, before the establishment of the PTF. Dr. Haroun 
Adamu's interim report on the activities of PTF shows that N135 billion out of the N146 billion was squandered, possibly through over-invoicing, over supplies, supplying expired materials, wrong project priorities, settling perceived troubles spots, like the army and the police, and blatant thievery".

Having all this in mind (i.e. the hyper-corrupt state of Nigeria) Chinua Achebe reacted by writing:

Nigeria is not a great country; it is one of the most disorderly nations in the world; it is one of the most corrupt, insensitive, inefficient places under the sun; it is one of the most expensive countries and one of those that give the least value for money; it is dirty, callous, noisy, ostentatious, dishonest and vulgar...it is among the most unpleasant places on earth (Reno, 1999).

With the heartbreaking fund that has been set aside for the issue of poverty eradication in Nigeria (e.g. 2.6 billion nairas during Shagari's regime, and 500 billion nairas under Buhari's civilian regime), poverty should have been reduced to history in the country long time ago. However, corruption and its corollary mismanagement/misappropriation of fund by politicians mostly did not (and will not) allow that.

- Hypocrisy on the part of World Bank and IMF: The adoption of SAP by Gen. Babangida as a remedy or route to Nigeria's freedom from poverty and dependence was an initiative of the International Monetary Fund (IMF). However, instead of SAP saving Nigeria, it launched it into infernal pandemonium of poverty, inflation and dependency. During the years of SAP, naira depreciated up to $80 \%$ against US dollars, inflation also was erratic, jumping from $16 \%$ to $56 \%$ in 1987 to 1988 and then dropping to $7 \%$ in 1990 and back to $50 \%$ in 1992 (Jaja et al., 2015). This, of course, saw poverty elevating rather than mitigating in the country.

- Unnecessary imitation: Some of the poverty alleviation programmes in Nigeria were all copied from one country or the other without proper consideration of the Nigerian environment. According to Jaja et al. (2015) the establishment of the People's Bank under Babangida was copied from Grameen Bank in Bangladesh without first considering the necessary. This was the reason why despite the over 100 billion nairas speculated to have been invested into phantom projects (which were Better Life Programme (BLP), DFRRI and People's Bank) ended as a waste. Hence the imitated programmes rather than working ended as "embarrassing disappointment" and mistake in Nigeria.

Aside from the above, other reasons for the failure of poverty alleviation programmes in Nigeria, according to Hussaini (2014) are a lack of clearly defined policy framework with proper guidelines for poverty alleviation, political interference, policy and macroeconomic dislocation, and political deception.

\section{CONCLUSION}

Based on what is presented in this paper, it becomes lucid and clear that there has been a long walk towards poverty eradication in Nigeria. The government and different internal and external organizations/institutions have tried in one way or the other to redeem Nigeria's vast population from ignominious poverty they were (and are still) wallowing in. However, despite their efforts, which could be seen in different poverty alleviation programmes they have pursued in the country, poverty refuses to get defeated as a result of some already-seen issues or problems which they, consciously and unconsciously, caused for themselves and Nigerians at large in the pursuit of the programmes.

\section{RECOMMENDATIONS}

To mitigate poverty in Nigeria, the following recommendations, if examined and implemented, would help out: 
i. As government disburse money for poverty eradication in the country, it should also ensure frequent probing or inquiry into how the money allotted is being used by those in charge of the programs to avoid looting and ensure proper utilization of funds. This should be done at least every three months.

ii. The ritual of program and policy abandonment by every new regime should either be put to stop or drastically reduced, for continuity is the womb of success.

iii. There should be a thorough examination or scrutinization of policies and any program aimed at poverty alleviation before its adoption in Nigeria, no matter where the program or policy might have worked successfully because every country on earth has its peculiarities.

iv. There ought to be a zestful effort towards development of local industries and infrastructures as this will reduce dependency, unemployment and in turn poverty.

v. Government, together with non-governmental organizations and persons of goodwill and benevolence should strive to assist most, if not all, able-bodied/sound-minded individuals of talents and skills in every possible way so they could develop themselves and their talents the more for the overall betterment of Nigeria.

vi. Skill acquisition programs should be taught with all vehemence and seriousness right from secondary school level as this will, directly and indirectly, reduce unemployment (which is one of the causes of poverty) rate in the country.

vii. Provision of basic education to all the gender and tribe, this should also be done seriously in order to swiftly bastardize illiteracy in all its forms and every nook and cranny of the country.

\section{REFERENCE}

Aiyedogbon, J. O., \& Ohwofasa, B. O. (2012). Poverty and youth unemployment in Nigeria, 1987-2011. International Journal of Business and Social Science, 3(20), 269-279.

Barder, O. M. (2009). What is Poverty Reduction? Center for Global Development Working Paper, (170), 1-22.

Hussaini, M. (2014). Poverty alleviation programs in Nigeria: Issues and challenges. International Journal of Development Research, 4(3), 717-720.

Irouke, A., Vitalis, M., \& Moses, A. A. (2017). An Evaluation of Shagari Housing Programme: A Case Study of three Towns: Abakaliki in Ebonyi State; Lokoja in Kogi State; Mbano in Imo State, Nigeria. International Journal of Geography and Environmental Management, 3(3), 58-67.

Jaja, B. N., Lingsma, H., Schweizer, T. A., Thorpe, K. E., Steyerberg, E. W., \& Macdonald, R. L. (2015). Prognostic value of premorbid hypertension and neurological status in aneurysmal subarachnoid hemorrhage: pooled analyses of individual patient data in the SAHIT repository. Journal of neurosurgery, 122(3), 644-652.

Mohammed, S. (2018). Poverty alleviation in nigeria: the role of information communication technology. Retrieved on 12th February.

Musa, U. F., Abdullah, M. A. I. L. B., \& Wahid, R. (2016). Politics of Poverty Alleviation Programs in Nigeria: Challenges and Prospects. Journal of Education and Social Sciences, 4, 2289-9855.

Obadan, M. I. (2001). Poverty reduction in Nigeria: The way forward. CBN economic and financial review, 39(4), 159-188.

Okunmadewa, F., Olaniyan, O., Yusuf, S., Bankole, A., Oyeranti, O., Omonona, B., . . Kolawole, K. (2005). Human capital, institutions and poverty in rural Nigeria. Report submitted to AERC.

Olotu, A., Salami, R., \& Akeremale, I. (2015). Poverty and rate of unemployment in Nigeria. Ijm, 2(1), 1-2.

Reno, W. (1999). Crisis and (no) reform in Nigeria's politics. African Studies Review, 42(1), 105-124.

Taiwo, J. N., \& Agwu, E. (2016). Problems and Prospects of Poverty Alleviation Programmes in Nigeria. International Journal of Business and Management Review, 4(6), 18-30.

Vyas, V., \& Bhargava, P. (1995). Public intervention for poverty alleviation: An overview. Economic and Political Weekly, 2559-2572. 